\title{
Paul Delaroche: The Reception of his Work in Russia*
}

\author{
M. A. Chernysheva \\ St. Petersburg State University, \\ 7-9, Universitetskaya emb., St. Petersburg, 199034, Russian Federation
}

For citation: Chernysheva, Maria. "Paul Delaroche: The Reception of his Work in Russia". Vestnik of Saint Petersburg University. Arts 9, no. 3 (2019): 577-589. https://doi.org/10.21638/spbu15.2019.308

Despite the existing body of literature on Paul Delaroche, this article is the first attempt to seriously assess his reception in nineteenth-century Russia. A study of how Delaroche was received by Russian critics, collectors and artists allows us take a new look both at the scale of his significance for nineteenth-century art as a whole and at certain key aspects of Russian artistic culture. The author analyses reviews of Delaroche's work in the Russian press, including some never previously discussed, and comments on Horace Vernet's celebrated statement that: "The emperor [Nicholas I] spoke with me at length about Delaroche. He has all his prints". Looking at Anatoly Demidov's patronage of Delaroche, the article also touches on the Russian collector's relations with the tsar. The new concept of the "genre historique" that originated with Delaroche was taken up and developed most productively in Russia in the 1860s and 1870s, as the author demonstrates through an analysis of paintings by Vyacheslav Schwarz and Nikolay $\mathrm{Ge}$, noting that their treatment of subjects from history was possible only in the more liberal age of Alexander II. It was under Delaroche's influence that both Schwarz and Ge created typologically new images of power and of the monarch (of Ivan the Terrible and Peter the Great). In conclusion, the author draws attention to the paradoxical nature of Western self-identification by Russian nineteenth-century artists, which can be explained in part through a study of the Russian reception of the art of Delaroche.

Keywords: nineteenth-century Russian art, nineteenth-century French art, Russian-French artistic relations, historicism, realism, Paul Delaroche, Karl Bryullov, Vyacheslav Schwarz, Nikolay Ge.

There have been numerous studies on the resonance of the art of Paul Delaroche (1797-1856), surely one of the best-known artists in nineteenth-century Europe, who reinvented history painting as the "genre historique" [1-4]. Though his reception in Russia is mentioned tangentially, mainly in connection with nineteenth-century Russian collections of French painting [5, c. 13-4, 24-5; 6; 7], there has been little attention to Russian art criticism and to Delaroche's influence on Russian art itself ${ }^{1}$. This article represents a first attempt to fill this lacuna, adding to our understanding both of Delaroche's significance and of certain key aspects of Russian artistic culture.

One of Delaroche's first and most generous patrons in the 1830s was the wealthy Russian industrialist and art lover Anatoly Demidov (Anatole Demidoff; 1813-1870).

* The article is part of the research project "Historical Reflection in Russia of the $19^{\text {th }}$ Century. Art. Architecture. Music. Literature" (Saint Petersburg State University, project ID: 37591242).

Translation by Catherine Phillips.

${ }^{1}$ On some instances of Delaroche's influence on Russian artists see: [8; 9].

(c) Санкт-Петербургский государственный университет, 2019 
Resident mainly in France and Italy, he rarely visited his native land. Occupying a notable place in the display of paintings at Demidov's Villa San Donato near Florence was Delaroche's The Execution of Lady Jane Grey (1833; 246×297 cm; National Gallery, London), bought in the very year it was painted. The previous year Demidov had acquired the watercolour sketch for Delaroche's The Assassination of the Duke of Guise $(1832 ; 14 \times 25 \mathrm{~cm}$; Wallace Collection, London) and his collection also included several authors' versions of various compositions, mainly subjects from British history [6, p. 47]. Eugène Delacroix is said to have compared Delaroche with a vulgar boyar, seeking the obvious rather than the delicate, and to have hinted at the lack of taste of many wealthy patrons [10, p. 179], expressing disdain for both Delaroche and Demidov. It should be noted, however, that Demidov is also known to have bought Delacroix's works [6, p. 14].

Although Demidov had little interest in Russian art, he did patronise Karl Bryullov (Briullov; 1799-1852), from whom he commissioned the artist's most famous work, The Last Day of Pompeii (1833; $456.5 \times 651 \mathrm{~cm}$; State Russian Museum, St Petersburg). Shown in the same room as The Execution of Lady Jane Grey at the Salon of 1834 [11, p. 1-2], Bryullov's vast picture was by no means as enthusiastically received by critics or the public.

It was largely thanks to Bryullov's inclusion that Russian critics took a particular interest in the Salon of 1834, which not surprisingly led to some of the earliest mentions of Delaroche in the Russian press. An anonymous reviewer in Russia's first widely-circulated periodical, Library for Reading, took umbrage that French critics clearly preferred French artists over the Russian, whom "they excoriated! They excoriated to bits!" [12, p. 50]. Clearly of the opinion that this "mediocre" artist had unjustly won the success of which Bryullov was deserving, the reviewer implied that the artist was guilty of populism [12, p.45]. Yet within the context of Russian culture it was Bryullov who was to demonstrate a populist approach, his Last Day of Pompeii arousing almost universal admiration. Both artists were skilled in winning the hearts of the people with their work, but in very different ways ${ }^{2}$, and though Russian artist, critic and art historian Alexandre Benois was later to christen Bryullov "the Russian Delaroche" [14, p. 135], to my mind Bryullov remained indifferent to the French painter's main achievement, the creation of that new concept of the historical picture ${ }^{3}$.

The Salon of 1834 was a triumph not only for Delaroche but for Anatoly Demidov, who owned several of the best French works on show. The reviewer in Library for Reading cited a number of positive French reviews about it that appeared in L'Artiste and Revue de Paris, which proclaimed Demidov as owner of a gallery that promised to be one of the richest and most remarkable of the age $[12, \mathrm{p} .49]^{4}$. As I have shown elsewhere, the vastly different responses to Demidov's two main paintings at the Salon give a pronounced ambiguity to Demidov's decision to present The Last Day of Pompeii to Russian Emperor Nicholas I (r. 1825-1855). Relations between Demidov and Nicholas I were strained at best, the monarch making no secret of his dislike of the former. Wealthy, self-willed and ambitious, Demidov was closely involved in French cultural life, which the reactionary

2 See further: [13].

3 It has been suggested that when Bryullov painted The Death of Inês de Castro in 1834, it was as a direct response to The Execution of Lady Jane Grey [15, p. 8]. Even if that was true, it simply serves to emphasise the fundamental difference between the works in their treatment of subjects from history: the restrained, nuanced narrative of Delaroche is in marked contrast to the exaggerated, almost parodical drama of Bryullov.

4 The author of the review gives quotations from [16, p. 72; 17, p. 136]. 
Nicholas I saw as a hotbed of liberalism. Thus Demidov's decision to give the Russian ruler a work that had been more poorly received in Paris, art capital of Europe, than The Execution of Lady Jane Grey, widely acclaimed as outstanding, was part of an implicit dialogue between the two men regarding the conditions and significance of cultural priorities ${ }^{5}$.

In 1836 Demidov facilitated the visit to Russia of Delaroche's father-in-law Horace Vernet (1789-1863), who was well received at the Russian court and won Nicholas I's personal approbation. During a later visit to Russia in 1842-1843 Vernet sought to persuade the Tsar to entrust Delaroche with designing wall-paintings for St Isaac's Cathedral in St Petersburg, on which huge sums were being expended ${ }^{6}$. But Delaroche had no desire to travel to Russia and declined the opportunity to make his fortune in this way. It was Bryullov who was to head the team of Russian artists carrying out the work.

In June 1842 Vernet wrote from St Petersburg: "The emperor spoke with me at length about Delaroche. He has all his prints [18, p. 168]"7. This is a telling statement: Delaroche was the most reproduced painter of his generation, the favourite artist of the owner of Europe's largest dealership in fine art reproductions, Adolphe Goupil (1806-1893), who sold mainly works by contemporary artists. Delaroche's pictures were thus widely available as reproductive prints and later as photographs. Yet less than a year later, in February 1843, Vernet was to assert that Delaroche was unknown in Russia [18, p. 235-6].

This situation changed after Delaroche's death. In autumn 1858 Russia's first periodical devoted to photography, entitled simply Photography ${ }^{8}$, mentioned an album of works after Delaroche on sale in one of the largest print and picture shops in the Russian capital, that of Franz Velten: "Gathered here are all this artist's works $\langle\ldots\rangle$ captured in the most reliable fashion through photography $\langle\ldots\rangle$ The full publication costs 165 silver roubles" $[19$, p.202]. From the price and description it seems plain that the album in question was the magnificent set published by Goupil that very year, composed of superb photographic reproductions of nearly all of Delaroche's works by Robert Jefferson Bingham (1824/25-1870), with an essay on the artist's oeuvre and brief texts accompanying each illustration [20]. Largely thanks to his photographs of Delaroche's paintings [21, p. 187], Bingham had earned himself a reputation in France as the best reproductive photographer [22, p. 119-20]. His success set an important example to the publishers of Photography, in which the photographic supplement consisted largely of reproductions of paintings ${ }^{9}$.

Goupil issued his album of photographic reproductions of Delaroche's drawings and paintings after the artist's large posthumous show in Paris in the spring of 1857. It was

5 See further: [13].

${ }^{6}$ Designed by the architect Auguste de Montferrand, this was to be the largest Orthodox church in St Petersburg and remains one of the city's main sights.

7 In the early 1840s Delaroche himself presented prints after his paintings to Nicholas' sister Maria Pavlovna, Grand Duchess of Saxe-Weimar-Eisenach [2, p. 142]. As for the collection of prints mentioned by Vernet, we know nothing of when or how it reached Nicholas I, nor what it consisted of. The earliest mention of a print after Delaroche in the accession books of the Imperial Hermitage dates from 9 August 1842, some six weeks after Vernet's letter. This was a portrait of Peter the Great, engraved that same year by Louis Henriquel-Dupont. Only two more entries for prints after Delaroche relate to the reign of Nicholas I, in 1851 and 1852 [I, no. 2, ff. 40, 74, 87]. But prints belonging to Nicholas' private collection were not necessarily entered in the museum inventory.

8 The Russian title is Cветопись [Svetopis], literally "painting with light", an old word for photography. The journal was published by Grigory Ozhe, one of the first Russian photographers.

9 Although these photographs were greatly inferior to those of Bingham and they have faded over time. Amongst the first reproductions to appear in Photography was Bryullov's Last Day of Pompeii. 
probably at the sale held afterwards that two of Delaroche's sketches for unrealised frescoes in the Madeleine in Paris were purchased for the gallery of the Princes Yusupov. Mary Magdalene by the Body of Christ and Mary Magdalene and Angels at Christ's Tomb (both oil on card, $20 \times 42.5 \mathrm{~cm}$ ), once in the Yusupov Palace in St Petersburg, are today in the Hermitage Museum [23, p. 144-5; 7, p. 473, 823-4, nos. 217-8].

An event of pan-European cultural significance, the posthumous exhibition of 1857 was also reviewed in the Russian press. It was in an article signed "K. Shtakhel" in the liberal periodical Notes of the Fatherland that most space was devoted to thoughts on the exhibition and on the work of Delaroche overall [24]. Karl Shtakhel was the pseudonym of Nikolay Sazonov (1815-1862), a freethinking Russian nobleman and adventurer who had frittered away his inheritance and was now a notable figure on the European cultural scene. Based in France and Switzerland, Sazonov was acquainted with Charles Baudelaire and was not only one of the first reviewers to praise his poetry but was the first to translate his poems into any foreign language, i. e. into Russian ${ }^{10}$. An admirer of Delacroix, Baudelaire had little time for Delaroche, while Sazonov / Shtakhel saw Delaroche as a mediocre satellite of the great painter, a representative of a rather tepid form of Romanticism. Sazonov wrote that Delaroche "creates an outrageous combination of different public demands" [24, p. 36], yet another writer accusing the artist of populism, echoing the reviewer in Library for Reading in 1834. Sazonov described Delaroche's kind of painting as "not so much a picture in itself as an illustration to some tragedy or novel" [24, p. 37]. Yet he admitted the success of some of Delaroche's works, not least The Assassination of the Duke of Guise, and praised the artist's rendering of real historical details, a feature often remarked upon by critics: "In these pictures the wall-coverings, carpets, furniture, clothing, that is to say the velvet, satin, lace, ribbons and feathers, are executed skillfully and with historical veracity $[24, \text { p. } 38]^{\prime \prime 11}$.

Delaroche's influence in Russia reached its height in the 1860s and 1870s, a key role being played by his masterpiece Cromwell before the Coffin of Charles I. Although the original (Musée des Beaux-Arts, Nîmes) had been shown at the Salon of 1831, an authorised full-size copy was acquired in the 1850s by Count Nikolay Kushelev-Bezborodko (1849; $226 \times 291 \mathrm{~cm}$; Hermitage Museum, St Petersburg), whose St Petersburg mansion housed one of Russia's most important publicly accessible private collections. After the collector's death in 1861 his pictures were put on open display in the Imperial Academy of Arts under the terms of his will and it is no exaggeration to say that the Kushelev Gallery of contemporary Western painting was a valuable resource for Russian artists throughout the second half of the nineteenth century [5, p. 18 ${ }^{12}$.

A wave of interest in Delaroche among Russian critics was prompted in 1860 by an exhibition at the Society for the Encouragement of the Arts in St Petersburg, and an exhibition of works drawn from private collections held in the rooms of the Imperial

${ }^{10}$ In 1856 Sazonov / Shtakhel published an article giving a striking and perceptive analysis of Baudelaire's talent as a poet and including a translation of the poem Le Crépuscule du matin: [25]. Sazonov was mentioned by Alexander Herzen, Leo Tolstoy, Théodore de Banville and Karl Marx, amongst others. On Sazonov and Baudelaire see: [26; 27, p. 168-221].

${ }^{11}$ Less interesting but more positive was the review of Delaroche's work in another Russian journal in 1857, which declared the artist to be "one of the best French history painters; he has more successfully combined faithfulness and finish in details with the main meaning of the painting than any other of his kind" [28, p. 616].

${ }^{12}$ See also: [29]. 


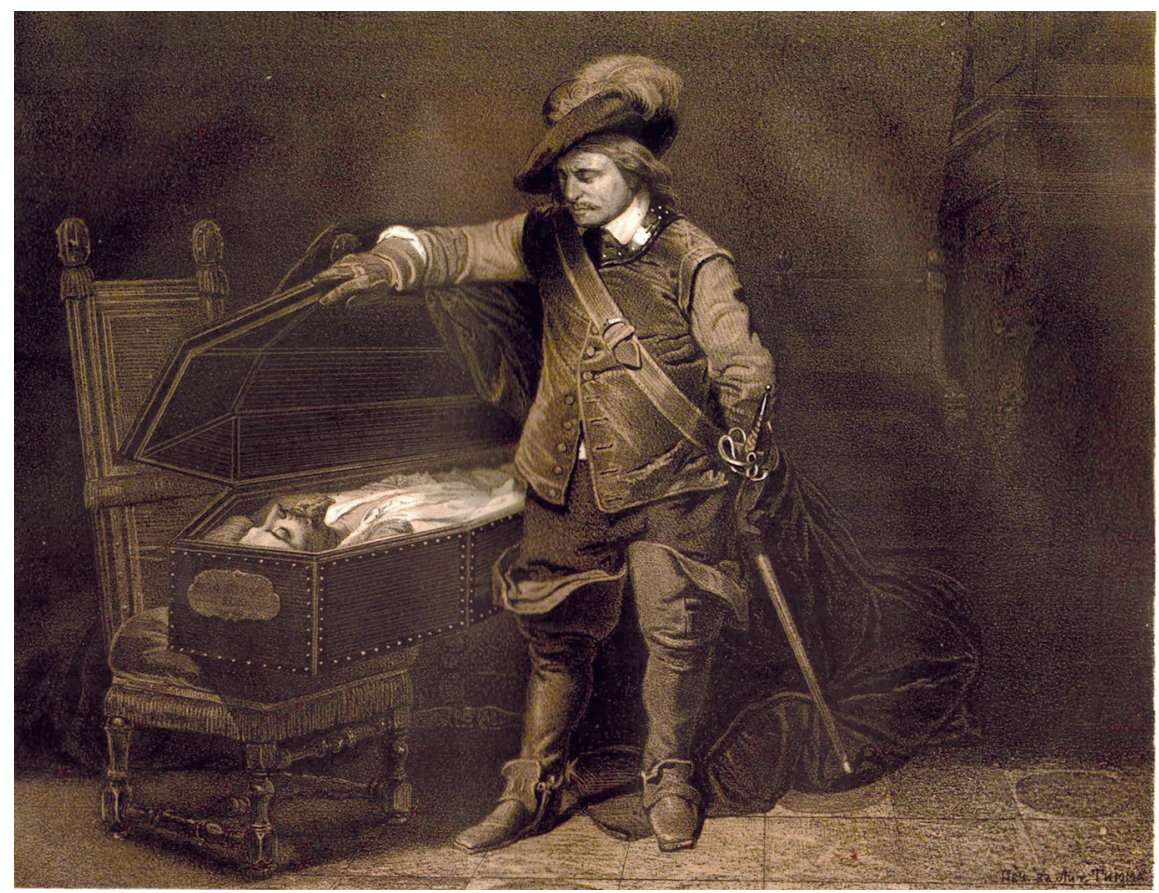

Fig. 1. Vasily Timm. Lithograph (1861) after Paul Delaroche. Cromwell before the Coffin of Charles I (1849) [31]

Academy of Arts the following spring [30, p. 52]. At both of them Delaroche's Cromwell... from the Kushelev-Bezborodko collection occupied a central place. It was the painting that was to do most to "inject" the French "genre historique" into Russian art.

In April 1861 Russian Art Leaflet published a lithograph of it by Vasily Timm (also the periodical's publisher), which was almost certainly the first Russian reproduction of any of Delaroche's works [31] (fig. 1). Russian Art Leaflet was a publication of unprecedented type in Russia, not only providing a survey of noteworthy events and people in Russian public life but attaching no less significance to visual material, in the form of lithographs. It was this that gave the title the word "art", since the periodical did not cover the art world as such. We should thus particularly note the inclusion of Delaroche's composition, since it provides evidence of the strong impression the painting had made on the wider public.

Two months later, Russian Art Leaflet published an article on the exhibition at the Academy, in which the critic Konstantin Varnek (Warnek; he signed himself " $K$. V.") described Delaroche as a philosopher-artist, exclaiming enthusiastically: "What a terrible moment the artist has chosen. Concentrated in this moment, as if in its very nucleus, is the whole of the English revolution" [32, p. 65, 68].

Overall the Academy exhibition prompted an extremely wide range of responses to Delaroche, by no means all of them positive. Some asserted that "Delaroche is the continuation of Academicism", lacking in creative force [33, p. 149], while others lamented that the artist was coming dangerously close to Realism in his choice of subjects [34, p. 654].

Amongst Delaroche's main admirers was Vladimir Stasov (1824-1906), the leading art critic in the second half of the nineteenth century. Historian, archivist and bibliogra- 
pher, Stasov ran the arts section at the Imperial Public Library. He had made his name as an opponent of Academicism and chief proponent of a national school of Realist art. His enthusiasm for Delaroche does not sit entirely happily with this reputation, but it probably dated from his earlier career, when he spent several years as secretary and artistic consultant to Anatoly Demidov, serving as his librarian at the Villa San Donato from 1851. Stasov mentioned Delaroche repeatedly in articles from the late 1850s onwards, praising his "historical realism" [35, p. 94], declaring him to be a rare artist with "a true gift for historicity" $[36$, p. 26] and to have been "one of the most advanced artists in France and Europe" [37, col. 346]. Towards the end of his life Stasov took a sideswipe at Modernism: "Paul Delaroche enjoyed considerable fame and admiration in Russia amongst all our artists. By some strange circumstances, as amazing as it is honourable to us, Paul Delaroche was far more loved in Russia than he was in France. Admittedly he enjoyed the highest honours in his native land in the 30 s and 40 s and was much eulogised. But in the 50s they suddenly cooled towards him, calling him a mere 'painter of the bourgeoisie', creator of 'historical anecdotes' in painting, an artist incapable of truly sublime art, and preferring Delacroix to him, but why? Simply for his [Delacroix's] brilliant, talented colours $<\ldots>$ But it was not so in Russia. Colours alone and virtuoso brushwork have never been enough to satisfy our artistic requirements; talented content and expression in a painting play a huge, even primary role for us..." [38, p.93].

With this turning point in the Russian reception of Delaroche in the 1860s, not only did the wider public become aware of him, but artists started to imitate him. In addition to numerous instances of superficial, fragmentary and approximate borrowings, his art prompted original developments within a new context of the concept of the history painting (the historical picture) as such. Superb examples of this are to be found in the work of two artists of the succeeding generation, Vyacheslav Schwarz (Schwartz, Shvarts) (1838-1869) and Nikolay Ge (1831-1894), who were among the best Russian painters of their age. They applied the new understanding of the historical picture to Russian material.

For his examination at the Academy, in late 1861 Schwarz presented a large cartoon, Ivan the Terrible by the Body of the Son he Murdered (1861; charcoal and chalk on card, $148.9 \times 211.1 \mathrm{~cm}$; State Russian Museum, St. Petersburg) (fig. 2), for which he received the First Silver Medal. This may not have been the highest possible award, but Stasov later wrote that it was with Ivan the Terrible... that "our true history painting began", - admitting: "I have always thought that Schwarz's cartoon is, in its main two figures, equal to one great European creation, Cromwell by the Coffin of Charles I by Delaroche" [39, p.52]. There are many things in it that recall Delaroche's picture: its subject; the narrative treatment with a powerful man in a state of immobility beside the corpse of his victim; the angle at which the dead body is shown; the mighty ruler's grasp of some physical attribute of the corpse (Cromwell holds the coffin's lid, Ivan the Terrible grips the shroud); the rumpled attire (Cromwell's glove is torn, Ivan's kaftan has come partly unbuttoned); the dark space that encloses the figures. In Schwarz's picture the pose of Ivan the Terrible, heavily and despondently slumped in his chair, summons up associations with another of Delaroche's creations, Napoleon at Fontainebleau $(1845 ; 180.5 \times 137.5 \mathrm{~cm}$; Museum der bildenden Künste, Leipzig), and we should not ignore that Schwarz had been in Germany in the first half of 1861, spending most of his time in Berlin studying under Julius Schrader (1815-1900), whose own work was influenced by Delaroche. 


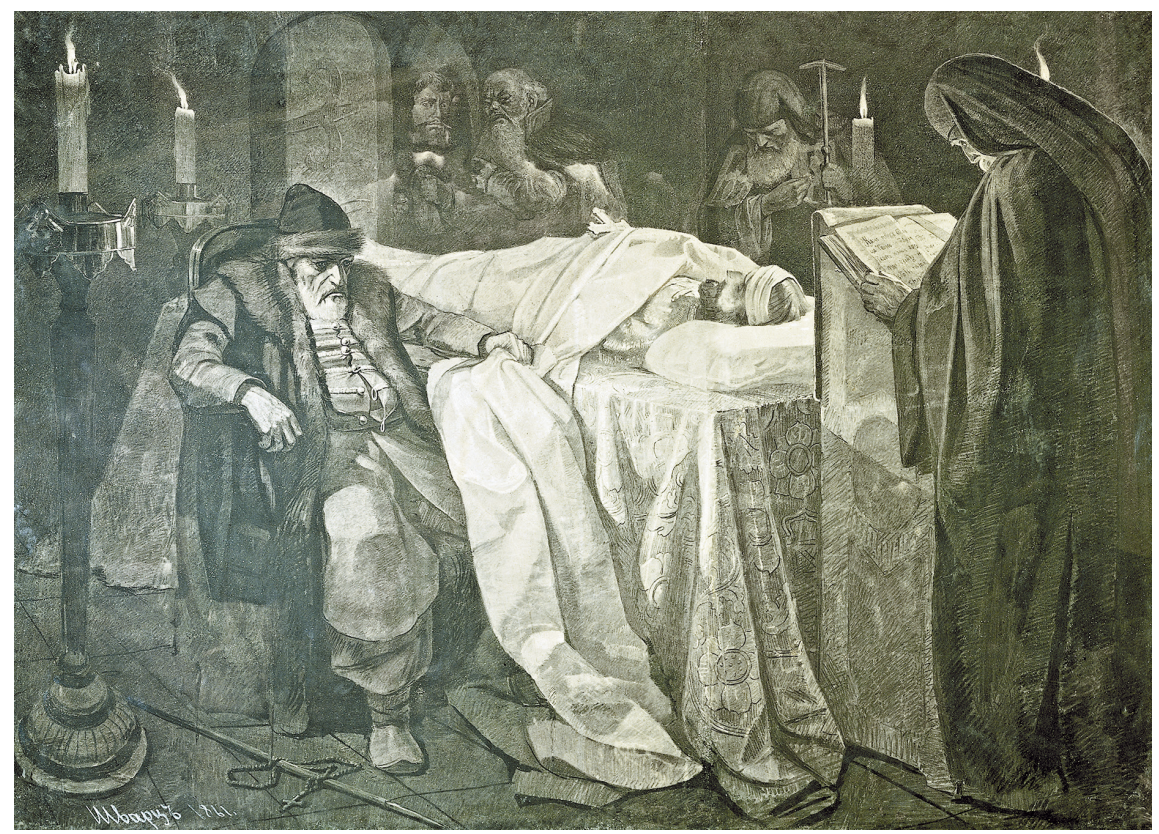

Fig. 2. Vyacheslav Schwarz. Ivan the Terrible by the Body of the Son he Murdered (1861). State Russian Museum, St. Petersburg

Ivan the Terrible... was the first fruitful development in Russian art of Delaroche's concept of the historical picture. Best manifested in Cromwell..., that concept was based on a rejection of the classical rhetoric of history painting, which demanded the clear and dramatic representation of some significant event. Now historical meaning was conveyed through secondary episodes, preceding or succeeding the main event, with the heroes seeming to forget their exclusive status and role. Yet the meaning with which Delaroche and Schwarz imbued their works was somewhat different.

In his review of the Salon of 1831, Heinrich Heine paid particular attention to Delaroche's Cromwell..., observing what most interested visitors to the exhibition: "All who looked at the picture of Cromwell were generally busy in conjecture as to what were his reflections by the coffin of the dead Charles" [40, p. 80]. Reports variously stated that Cromwell went to the coffin at night and stood sunk in complex, lengthy reflection that may well have included repentance, or that he came in the daytime and simply cast an indifferent, prosaic glance at his dead opponent. Heine felt that Delaroche had the second "more democratic legend" in mind [40, p. 81]. Delaroche's Cromwell... is suffused with the bourgeois liberal spirit not only in showing a king overthrown by civil conflict but in that it treats royal power as a replaceable political project rather than as an absolute value, as something that can be looked upon calmly and prosaically. Yet Delaroche's work contains nothing revolutionary or anti-monarchical. Commissioned by the state in the reign of Charles X, it was intended to refer to the French Revolution that sent Louis XVI to the guillotine, with the implicit understanding that it was a national tragedy. Overall, the picture reads as a compromise: revolutionary terror is horrible and impermissible, but absolutism as it existed before the revolution should never return. How far this intellectual compromise was deliberate on Delaroche's part is hard to say, but history itself has con- 
firmed its relevancy: Cromwell... was completed and shown to the public just as the July Revolution removed Charles X from the throne and Louis-Philippe was elected to replace him: the "citizen-king" or "bourgeois king" whom the quintessential autocrat Nicholas I of Russia never considered his equal in status.

Unlike Delaroche's Cromwell, Ivan the Terrible in Schwarz's cartoon does not pass by but seems to sit beside the corpse for hours, even days. This is not simply an image of a remorseful filicide. The tsar's dominant presence in the darkness steeped in death becomes a metaphor for Ivan's savage, mad, monstrous reign, in which he viciously tortured thousands of innocent people. We know from Schwarz's correspondence that he reread Nikolay Karamzin's History of the Russian State [41, p. 80] while working on the cartoon and indeed we find in that text a description which perfectly fits his picture: "There where the blood of the innocent had been shed over so many years sat Ivan, stained with his own son's blood, numbed and unmoving beside the corpse, without food or sleep, for several days" [42, p. 349]. Karamzin's momentous opus, written with the support of Alexander I (r. 1801-1825) and first published during his reign, did much to awaken Russian society's interest in national history. One of Karamzin's greatest achievements was that, while an ardent supporter of autocracy, he made no attempt to suppress inconvenient facts. For the very first time Russians could read of the full horrendous scale of Ivan IV's crimes and learn how a monarch might be guilty of bringing down his own people. And it was Schwarz who first gave visual form to this bloody filicidal king, even if such a thing was possible only in the reign of the liberal Alexander II (r. 1855-1881), the tsar who put an end to serfdom: it could certainly never have happened in the reign of Alexander's father Nicholas I. Paralleling the significance of Delaroche's Cromwell... for European painting, Schwartz's Ivan the Terrible... gave Russian painting a typologically new image of power that was born out of the liberalisation of culture.

Schwarz used the cartoon as the basis for a smaller painting during a stay in Paris 1863-64 (1864; $71 \times 89 \mathrm{~cm}$; Tretyakov Gallery, Moscow) (fig. 3) where he became an admirer of Ernest Meissonier (1815-91) and Jean-Léon Gérôme (1824-1904), the latter Delaroche's most important pupil ${ }^{13}$.

Stasov reported that Nikolay Ge "in conversation with friends spoke $<\ldots>$ of his great $<\ldots\rangle$ love and respect" for Delaroche [38, p. 85] and the most obvious and fascinating response to Delaroche's work is found in Ge's famous Peter I Interrogating Tsarevich Alexey (1871; $135.7 \times 173 \mathrm{~cm}$; Tretyakov Gallery, Moscow) (fig. 4) $)^{14}$. Shown towards the end of 1871 at the first Travelling (Wanderers') Exhibition ${ }^{15}$, so great was its success with the public and with critics that it became the focal point of the whole show. Stasov was not alone in noting its similarities to Delaroche's Cromwell... [43, p. 208-9; 38, p. 236]. Both scenes are set in an interior with a geometrical patterned stone floor. In one we see a chair upholstered in red velvet and a coffin; in the other an armchair upholstered in red velvet and a table. Both scenes contain two figures in silent, one-sided communication: Cromwell lifting the lid of the coffin addresses his thoughts to the unresponsive corpse of the

13 According to Stasov, Schwarz was particularly proud of his acquaintance with Gérôme, who presented him with inscribed photographic reproductions of his paintings [39, p. 113].

${ }_{14}$ Delaroche also took up the subject of Peter I in 1838, when Demidov commissioned him to paint a historic portrait of the first Russian emperor (Kunsthalle, Hamburg).

15 A group of artists organised a progressive type of exhibition that was new in Russia, the independent travelling exhibition which gave them their name, the Wanderers or the Itinerants. 


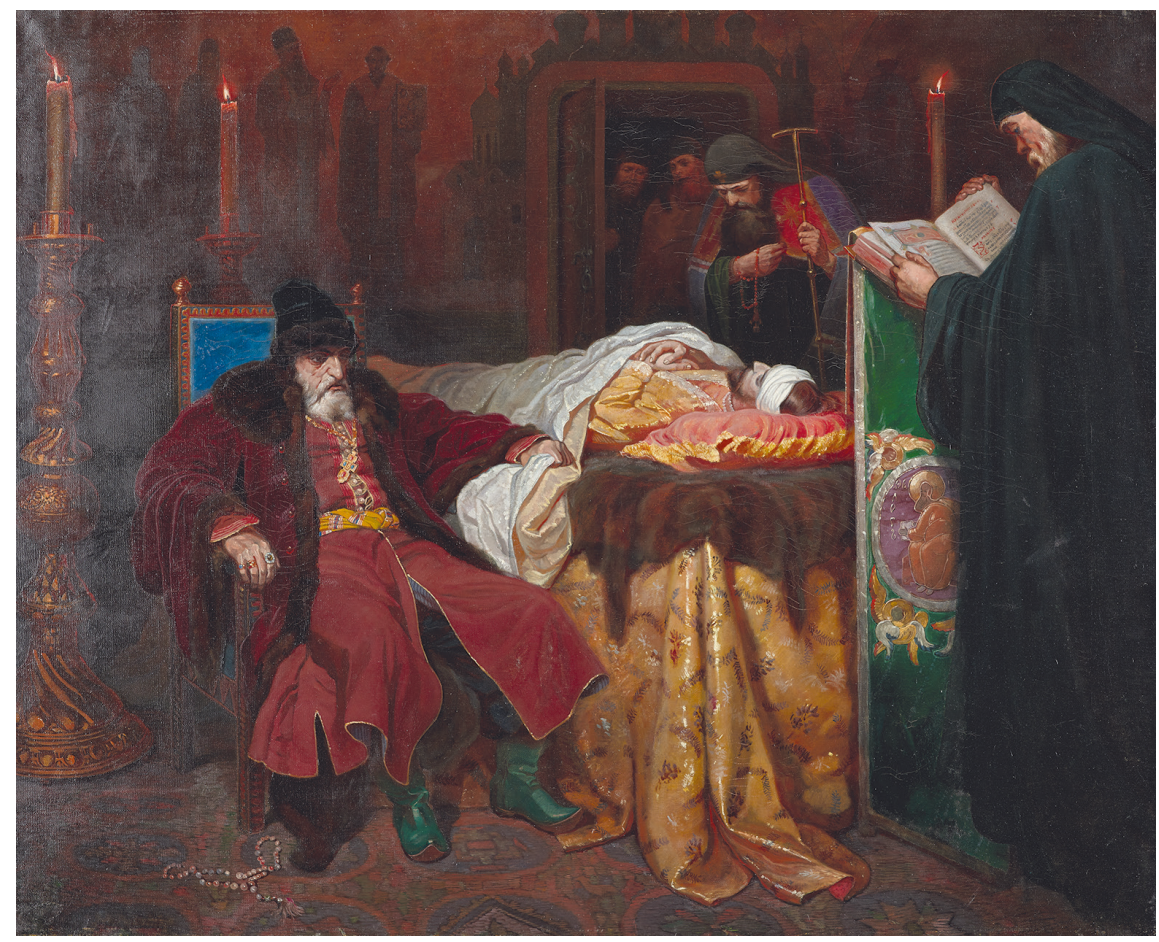

Fig. 3. Vyacheslav Schwarz. Ivan the Terrible by the Body of the Son he Murdered (1864). Tretyakov Gallery, Moscow

king; Peter awaits an answer from his son, who remains silent, avoiding his father's gaze. Both Cromwell and Peter occupy the right side of the scene. In the foreshortened coffin, Charles' body with its bloody slash across the throat seems truncated, pitiful. Compared with Peter, Alexey seems slender, somewhat reduced in size.

Unlike Delaroche and Schwarz, Ge depicts the event preceding the tragedy, in this case the secret murder of the heir to the throne by order of his father Peter. Doubting his son's loyalty and not wishing to make him his heir, Peter accused Alexey of treason, subjecting him to interrogation and torture. Nothing of this tragic, terrible tale is reflected in the restrained and somewhat prosaic rhetoric of Ge's picture, which thus becomes an analogy for what Stasov perceptively described as Delaroche's "note of restraint" [38, p. 109]. Neither in Peter I... nor in Cromwell... are events stirring or passions inflamed.

Another feature that marks the works of both Ge and Delaroche is the absence of the artist's opinion, of any assessment of the characters' actions. Viewers are given the freedom to make their own moral judgments. In this sense Ge's Peter I... went beyond not only Schwarz's Ivan the Terrible... but perhaps even Delaroche's Cromwell... Ge's contemporaries and later generations of art historians have seen in the work the assertion of their own - very different and at times diametrically opposed - historical beliefs. Supporters of Peter saw the picture as presenting a positive reading of events, in which the monarch sacrificed parental affection on the altar of state interests; critics read it as hinting at his cruel despotism; others appreciated its ambiguity, its neutral objectivity in showing how a single individual might combine good and bad, strength and weakness. 


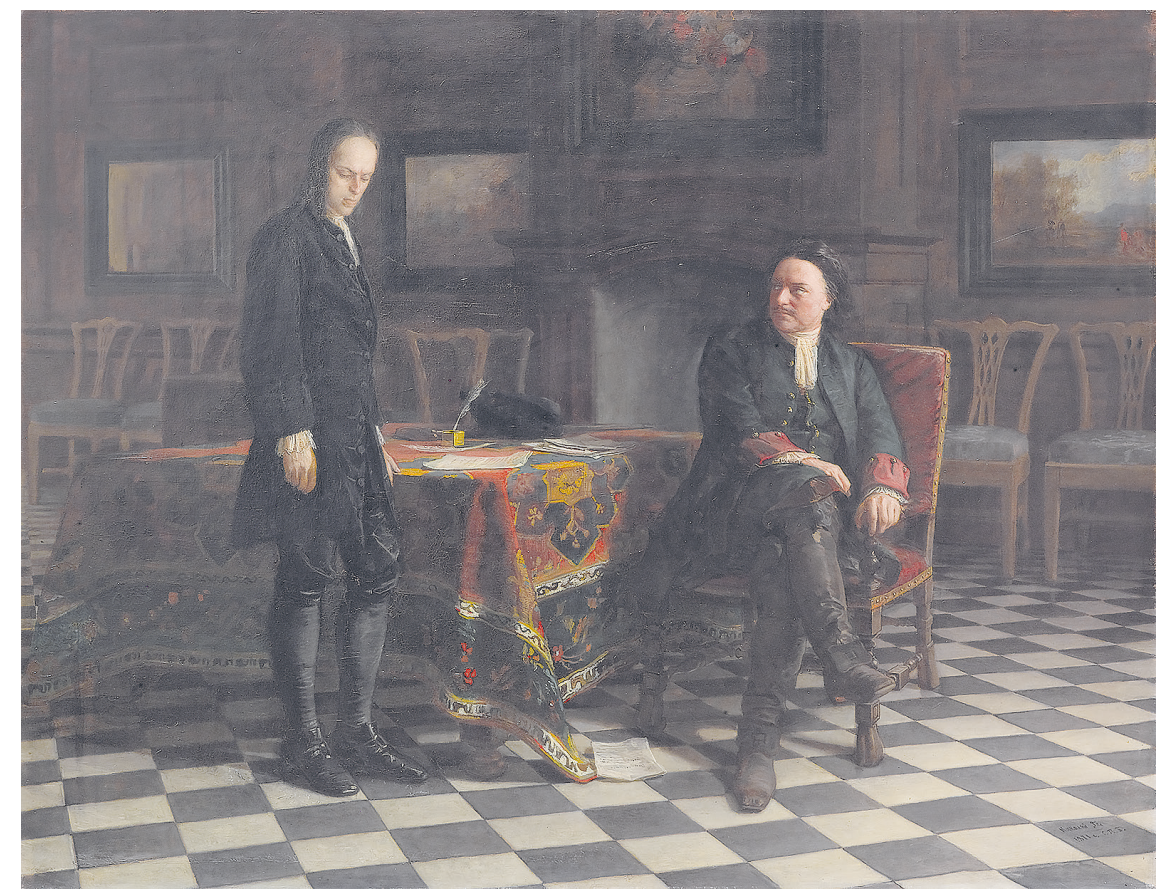
Moscow

Fig. 4. Nikolay Ge. Peter I interrogating Tsarevich Alexey (1871). Tretyakov Gallery,

The last reading is surely that closest to the artist's own intention. There is some reason to believe that Ge shared the views of historian Nikolay Kostomarov, whose research was also important to Schwarz. Kostomarov did not idealise Peter and never denied his despotism, coarseness and cruelty; he felt that there was no justification of his treatment of his own son; yet he admired Peter for his talent, his curiosity, his hard work, and his unswerving commitment to the reforms that he hoped would bring European culture to Russia and make the latter a truly European state [44].

In Ge's painting the image of the tsar is not defined by fatherhood but by something that brings us back to the works of Delaroche. Heine's words about Delaroche's Cromwell... might just as well be applied to Peter I: he is "a form as firm as earth", "brutal as a fact", "powerful without pathos, naturally supernatural, marvellously commonplace" [40, p. 81]. If the man whom Delaroche showed thus was not a monarch but the monarch's enemy, one for whom the brilliance of monarchy was not fitting, Ge went further in presenting the monarch himself in such a fashion. He was the first Russian artist to depict in paint a Russian ruler without emphasising the symbolic value of his power as supreme state functionary, the first to stress Peter's character as an energetic and effective pragmatist. Once again, such a representation could only happen in the age of positivism and bourgeois liberalism that dawned when Nicholas I was succeeded on the Russian throne by Alexander II. Indeed, Alexander was so pleased with Ge's picture that he wanted to acquire it (although he had to make do with an author's copy).

That Schwarz and Ge were Delaroche's main heirs in Russia is not without paradox. Both men occupy a more important place in the history of Russian art than Delaroche in 
the history of French art. Moreover, if Delaroche is associated with moderate Romanticism and Academicism, Schwarz and Ge are seen as proponents of Realism, though they had nothing in common with the radical leader of French Realism, Gustave Courbet. Both were born into noble families and received a good upbringing and education; both studied at the Academy and never joined the opposition to it. They enjoyed respect and support in official circles. Schwarz and Ge saw themselves as history painters. But in Russia they presented the most up-to-date and most daring achievements, of the kind identified in the 1860s and 1870s with Realism. At the first Travelling Exhibition of 1871, for instance, it was around Ge's history painting, Peter I Interrogating Tsarevich Alexey, and not around the genre scenes, landscapes and portraits that made up the absolute majority of works on display, that critics gave most thought to Realism.

A study of the Russian reception of Delaroche makes clear the disjunction in Western identifications of Russian nineteenth-century artists: art perceived as Realist and as the most innovative in the Russian context looks in the international context more like proAcademic compromise. The favourite French painters of Schwarz and Ge - and of many other Russian artists of their generation - were not Delacroix or Courbet, and certainly not the newly emerging Impressionists, but Delaroche, Gérôme and Meissonnier ${ }^{16}$.

But we might also look at this situation somewhat differently, as the consequence of and evidence for the particular structure of Russian nineteenth-century art. Russian art was far more unified than French art, with broader and less precise internal divisions according to aesthetic and ideological principles. The aesthetic and ideological confrontation between Realism and Academism took place in Russia in the 1860s and 1870s largely inside the heads of art critics rather than in art itself ${ }^{17}$ Stasov, denouncer of Academism and apologist for Russian national Realism, exaggerated the Realist tendentiousness of Schwarz and Ge, which did not prevent him from simultaneously enthusing about Delaroche. Perhaps because deep inside he attributed to Delaroche the convictions of a Realist painter?

\section{References}

1. Bann, Stephen, and Stéphane Paccoud, eds. L'Invention du passé: Histoires de coeur et dépée en Europe 1802-1850. Paris: Hazan, 2014.

2. Bann, Stephen. "Paul Delaroche's German Reception". In Dialog und Differenzen: 1789-1870. Deutsch-französische Kunstbeziehungen. Les relations franco-allemandes, Hrsg. Isabelle Jansen und Friederike Kitschen, 139-52. Berlin; München: Deutscher Kunstverlag, 2010.

3. Allard, Sébastien. "Quelques réflexions sur Paul Delaroche et son influence en Europe". In Les artistes étrangers à Paris: de la fin du Moyen Age aux années 1920, édité par Marie-Claude Chaudonneret, 193-202. Berne; Berlin; Bruxelles; Francfort sur le Main; New York; Oxford; Vienne: Peter Lang, 2007.

${ }^{16}$ Alexandre Benois himself mentioned this when talking of the generation of artists in the second half of the nineteenth century who preceded the World of Art Movement: "all of them, even the best <...> to the last man, were so unprepared that they became fatally enthralled by such 'ephemeral' phenomena as Delaroche, Vernet, Piloty, Munkácsy and, at best, Matejko, Fortuny and Meissonier" [14, p. 144]. Elizabeth Valkenier particularly remarked on the lack of interest in "the innovative trends in the West" of the early Wanderers [45, p. 54; 46, p. 45-8]. Rosalind Blakesley pointed out that Russian Realist painters "looked not to the giants of French modernism but elsewhere for inspiration" [47, p. 252].

${ }_{17}$ This is indicated in some of the most recent literature: [48; 49]. In her book Russian Realist Art Valkenier convincingly showed that those Russian artists of the first generation of Wanderers who were called Realists sought to raise and modernise their cultural status rather than to apply Realist principles in their art. Her conclusions and those of Shabanov [49] were supported by Blakesely [47, p. 242]. 
4. Mainardi, Patricia. Art and Politics of the Second Empire: The Universal Expositions of 1855 and 1867. New Haven; London: Yale University Press, 1987.

5. Asvarishch, Boris. Kushelev Gallery: Western European Painting of the XIX century. St. Petersburg: Gosudarstvennyi Ermitazh Publ., 1993. (In Russian)

6. Haskell, F., S. Duffy, R. Wenley, and D. Edge. Anatole Demidoff: Prince of San Donato (1812-70), ed. by Francis Haskell. London: Trustees of the Wallace Collection, 1994.

7. Savinskaia, Liubov'. The Art collection of the Princes Yusupov. Moscow: s. n., 2017. (In Russian)

8. Chernysheva, Maria. "Paul Delaroche's Works from the Collection of Anatoly Demidov and Their Significance for Russian Artists of the 19th Century". In Aktual'nye problemy teorii i istorii iskusstva, ed. by Svetlana Mal'tseva et al., 597-604. St. Petersburg: NP-Print Publ., 2016. http://dx.doi.org/10.18688/ aa166-7-64. (In Russian)

9. Chernysheva, Maria. "Complete Picture as a Conceptual Draft: Towards the Genesis of the Historical Genre in Russian Art”. Die Welt der Slaven 62, no. 1 (2017): 79-99. (In Russian)

10. Bann, Stephen. Paul Delaroche: History Painted. London: Reaktion Books, 1997.

11. L'Observateur aux salons de 1834. Paris: Imprimerie de Chassaignon, [s. d.].

12. "The Exhibition of Fine Arts in Paris". Biblioteka dlia chteniia III (1834): 44-51. (In Russian)

13. Chernysheva, Maria. "A Painting as a Gift to the Emperor: The Symbolic Aspect of Anatoly Demidov's Relationship with Nicholas I”. Novoe literaturnoe obozrenie 6, no. 154 (2018): 118-30. https://www. nlobooks.ru/magazines/novoe_literaturnoe_obozrenie/154_nlo_6_2018/article/20436/. (In Russian)

14. Benua, Aleksandr. The History of Russian Painting in the XIX century. Comp. by Vsevolod Volodarskii. $3^{\text {rd }}$ ed. Moscow: Respublika Publ., 1999. (In Russian)

15. Allenova, Ol'ga. Karl Bryullov. Moscow: Trilistnik Publ., 2000. (In Russian)

16. L’Artiste VII (1834): 72.

17. Revue de Paris III (1834): 131-6.

18. Joseph, Carle et Horace Vernet: Correspondance et biographies. Paris: J. Hetzel, 1864.

19. Svetopis', no. 8-9 (1858): 202. (In Russian)

20. Oeuvre de Paul Delaroche, reproduit en photographie par Bingham: Accompagné d'une notice sur la vie et les ouvrages de Paul Delaroche par Henri Delaborde: Et du catalogue raisonné de l'oeuvre par Jules Goddé. Paris: Goupil, 1858.

21. La Lumière, November 20, 1858: 187.

22. Bann, Stephen. Parallel Lines: Printmakers, Painters and Photographers in Nineteenth Century France. New Haven: Yale University Press, 2001.

23. The Hermitage. Catalogue of Western European Painting. 16 vols. Florence: Giunti, 1983, vol. 11: Berezina, Valentina. French Painting: Early and Mid-nineteenth Century.

24. Shtakhel', Karl. "Review of French Periodicals, Books and Brochures". Otechestvennye zapiski 113 (1857): 34-51. (In Russian)

25. Shtakhel', Karl. "The Latest Poetry in France, Italy and England". Otechestvennye zapiski 104 (1856): 1-26. (In Russian)

26. Guyaux, André. "Baudelaire et Sazonov". L’Année Baudelaire: Baudelaire toujours: Hommage à Claude Pichois, no 9-10 (2007): 143-152.

27. Fokin, Sergei. Passages: Baudelaire Studies. St. Petersburg: Machina Publ., 2011. (In Russian)

28. "Paul Delaroche”. Obshchezanimatel'nyi vestnik, no. 17 (1857): 614-6. (In Russian)

29. Gray, Rosalind Polly. "The Golitsyn and Kushelev-Bezborodko Collections and Their Role in the Evolution of Public Galleries in Russia”. Oxford Slavonic Papers 31 (1998): 51-67.

30. Index of Collection of Paintings and Rare Works of Art Belonging to the Members of the Imperial House and private persons of Petersburg. St. Petersburg: Tip. Gogenfel'dena Publ., 1861. (In Russian)

31. Russian Art Leaflet, no. 12 (1861). (In Russian)

32. K. V. [Varnek, Konstantin]. "Reminiscences of the Exhibition of Paintings and Rare Works of Art at the Academy of Arts". Russkii khudozhestvennyi listok, no. 17 (1861): 65-8. (In Russian)

33. Zhemchuzhnikov, Lev. "Several Notes on the Last Exhibition at the St Petersburg Academy of Arts". Osnova, February (1861): 136-56. (In Russian)

34. F. U. [Ustrialov, Fedor]. "The Exhibition of Pictures and Rare Works of Art at the Academy of Arts in this Current Year”. Vek, no. 19 (1861): 652-5. (In Russian)

35. Stasov, Vladimir. "After the World's Exhibition". In Stasov, Vladimir. Izbrannye sochineniia: Zhivopis', skul'ptura, muzyka, ed. by Elena Stasova, comment. by M. Blinova and P. Shchipunov, 65-112. 3 vols. Moscow: Iskusstvo Publ., 1952, vol. 1. (In Russian) 
36. Stasov, Vladimir. "Art Exhibitions in 1879". In Stasov, Vladimir. Izbrannye sochineniia: Zhivopis', skul'ptura, muzyka, ed. by Elena Stasova, comment. by M. Blinova and P. Shipunov, 7-26. 3 vols. Moscow: Iskusstvo Publ., 1952, vol. 2. (In Russian)

37. Stasov, Vladimir. "The Jewish Tribe in the Works of European Art". In Stasov, Vladimir. Sobranie sochinenii. 1847-1886. 4 vols, 309-88. St. Petersburg: Tip. M. M. Stasiulevicha Publ., 1894, vol. 1. (In Russian)

38. Stasov, Vladimir. Nikolai Nikolaevich Ge: His Life, Works and Correspondence. Moscow: Tip. t-va I. N. Kushnereva i Ko Publ., 1904. (In Russian)

39. Stasov, Vladimir. "Vyacheslav Grigorevich Schwarz". Vestnik iziashchnykh iskusstv 2, iss. 1-2 (1884): 25-64, 112-42. (In Russian)

40. Heine, Heinrich. The Works. Transl. by Charles Godfrey Leland (Hans Breitmann). 12 vols. London: William Heinemann, 1893, vol. 4: The salon, or, Letters on Art, Music, Popular Life, and Politics.

41. Shvarts, Viacheslav. Correspondence, 1838-1869. Comp. and comment. by Stefan Taranushchenko, ed. and comment. by Marina Tarasova. Kursk: Polstar Publ., 2013. (In Russian)

42. Karamzin, Nikolai. History of the Russian State. 11 vols. $4^{\text {th }}$ ed. St. Petersburg: Tip. vdovy Pliushara Publ., 1834, vol. 9. (In Russian)

43. Stasov, Vladimir. "Wandering exhibition of 1871". In Stasov, Vladimir. Izbrannye sochineniia: Zhivopis', skul'ptura, muzyka, ed. by Elena Stasova, comment. by M. Blinova and P. Shchipunov, 205-16. 3 vols. Moscow: Iskusstvo Publ., 1952, vol. 1. (In Russian)

44. Kostomarov, Nikolai. “Tsarevich Alexey Petrovich (On the Painting by N.N.Ge)”. Drevniaia i novaia Rossiia. Ezhemesiachnyi istoricheskii illiustrirovannyi sbornik 1-2 (1875): 134-52. (In Russian)

45. Valkenier, Elizabeth Kridl. Russian Realist Art. The State and Society: The Peredvizhniki and Their Tradition. New York: Columbia University Press, 1989.

46. Valkenier, Elizabeth, Kridl. "Opening up to Europe. The Peredvizhniki and Miriskusniki Respond to the West". In Russian Art and the West: A Century of Dialogue in Painting, Architecture, and the Decorative Arts, ed. by Rosalind P. Blakesley and Susan E. Reid, 45-60. DeKalb: Northern Illinois University Press, 2007.

47. Blakesley, Rosalind Polly. The Russian Canvas: Painting in Imperial Russia, 1757-1881. New Haven: Yale University Press, 2016.

48. Bobrikov, Aleksei. Another History of Russian Art. Moscow: Novoe literaturnoe obozrenie Publ., 2012. (In Russian)

49. Shabanov, Andrei. The Wanderers: A Partnership Between the Commercial and Artistic Movement. Science ed. by Il'ia Dorochenkov. St. Petersburg: Evropeiskii universitet v Sankt-Peterburge Publ., 2015. (In Russian)

\section{Sources}

I. State Hermitage Museum. Catalogue of Prints in the Imperial Hermitage. Addition to Noth's Catalogue. Manuscript. (In Russian)

Author's information:

Maria A.Chernysheva — PhD, Associate Professor; mariachernysheva@mail.ru 